\title{
CONFLITO ENTRE COISAS JULGADAS: PREVALÊNCIA DA SEGUNDA, QUANDO NÃO RESCINDIDA
}

\author{
Eduardo Talamini ${ }^{1}$
}

\section{RESUMO}

O presente artigo analisa o conflito entre coisas julgadas e quais são as teorias que buscam resolver esse conflito. A partir do estudo das teses que defendem ou prevalecer a primeira sentença ou a segunda, conclui-se que a segunda coisa julgada deve prevalecer, se não desconstituída por ação rescisória - entendimento esse que foi o consagrado pelo Superior Tribunal de Justiça.

Palavras-chave: coisa julgada; conflito; ação rescisória, prevalência.

\section{INTRODUÇÃO}

A existência de coisa julgada constitui uma objeção processual. Em sua dimensão negativa (proibição de repetição de julgamento do mesmo objeto já decidido), ela constitui uma objeção processual. Vale dizer, é um defeito que pode e deve ser conhecido de ofício pelo juiz, impondose a negativa de resolução do mérito (CPC, arts. 337, VII e $\S 5^{\circ}$, e 485 , VI e $\S 3^{\circ}$ ). Igualmente a dimensão positiva da coisa julgada deve ser considerada pelo juiz independentemente de alegação da parte: cabe-lhe tomar como premissa necessária declaração contida no decisum de um primeiro processo que recai sobre uma questão prejudicial para o segundo processo.

Não se respeitando a coisa julgada, em qualquer de suas duas dimensões, se vier a ser proferida sentença de mérito, essa é rescindível (CPC, art. 966, IV). Nessa hipótese, vale a regra geral sobre o prazo decadencial para a ação rescisória, de dois anos contados do trânsito em julgado da decisão rescindenda (CPC, art. 975, caput).

O problema se põe quando se esgota tal prazo sem que a ação rescisória por ofensa à coisa julgada seja proposta. Nessa hipótese, discute-se qual pronunciamento deve prevalecer: a primeira sentença, cuja autoridade da coisa julgada foi ofendida, ou a segunda, proferida em ofensa à primeira mas não atacada oportunamente?

Não chega a haver um impasse tão marcante quando a segunda sentença viola o "aspecto positivo" da coisa julgada. Se a segunda sentença deixa de considerar uma premissa estabelecida no decisum da primeira sentença, estará afrontando a coisa julgada dessa primeira decisão - e por isso deveria ser rescindida -, mas, se não o for, poderá subsistir sem que exista um conflito prático entre os dois comandos (p. ex., no primeiro processo, em que se pretendeu a cobrança do principal, declarou-se no decisum que o crédito não existe; no segundo processo, em que se cobravam os juros do mesmo pretenso crédito, o juiz desconsidera o decisum anterior, que era prejudicial ao acolhimento da pretensão dos juros, e julga procedente a ação.

\footnotetext{
${ }^{1}$ Livre-docente em Direito processual civil (USP). Doutor e Mestre em Direito processual (USP). Professor associado de Direito processual civil (UFPR). Advogado em Curitiba, São Paulo e Brasília.
} 


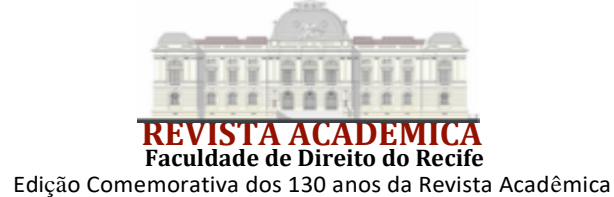

Nesse exemplo, decorrido in albis o prazo da rescisória contra a segunda sentença, será perfeitamente possível reconhecer a vigência e eficácia das duas - a primeira rejeitando o principal, a segunda condenando ao pagamento dos juros). ${ }^{2}$

Mas o problema avulta quando a segunda sentença, afrontando o "aspecto negativo" da coisa julgada, tornou a decidir exatamente o mesmo objeto já decidido pela primeira estabelecendo-se dois comandos inconciliáveis inclusive do ponto de vista prático. Segundo Sérgio Rizzi, tal questão seria discutida "menos pela expressão prática do que pela riqueza teórica". Mas atualmente ela está longe de ser um simples exercício doutrinário. Além de casos esparsos de há muito relatados em repertórios de jurisprudência, ${ }^{4}$ a questão tem agora sido posta com alguma frequência em determinados campos de litígios de direito público, notadamente, no das desapropriações. Por exemplo, há casos em que, depois de uma primeira sentença transitada em julgado na ação de desapropriação, o particular promove ação de "desapropriação indireta" e obtém nova indenização pelo mesmo imóvel objeto da primeira ação - sem que se constate no curso do processo a anterior coisa julgada nem se promova tempestivamente a rescisória contra a segunda sentença.

\section{A TESE DE QUE PREVALECERIA A PRIMEIRA SENTENÇA}

Uma parte da doutrina e da jurisprudência sustenta que deve prevalecer a primeira das duas sentenças.

Mas os fundamentos apresentados para se chegar a essa conclusão variam. Alguns sustentam a inexistência jurídica da segunda sentença, ofensiva à coisa julgada. ${ }^{5}$ Outros, embora descartem ser inexistente o segundo pronunciamento, reputam que o caráter constitucional da coisa julgada não permitiria que a segunda sentença prevalecesse sobre a primeira. ${ }^{6}$ Partem da premissa de que a ofensa a uma garantia constitucional implicaria vício cujo reconhecimento dispensaria ação rescisória ou, quando menos, não se submeteria ao prazo decadencial de dois anos.

\section{A EXISTÊNCIA JURÍDICA DA SEGUNDA SENTENÇA}

A sentença ofensiva a uma primeira coisa julgada é juridicamente existente. Apresenta-se o núcleo essencial para que uma sentença exista ${ }^{7}$ : há inquestionavelmente um novo comando jurisdicional, em conflito prático com o primeiro.

${ }^{2}$ MOREIRA, José Carlos Barbosa. Comentários ao CPC. 11. ed. Rio de Janeiro: Forense, 2003. p. 226-227. v. 5, n. 133.

${ }^{3}$ RIZZI, Sérgio. Ação rescisória. São Paulo: RT, 1979. p. 133.n. 81.

${ }^{4}$ Veja-se, p. ex., NEGRÃO, Theotonio. Código de Processo Civil e legislação processual em vigor. 35. ed. São Paulo: Saraiva, 2003. n. 3, art. 471.

${ }^{5}$ V. RSTJ, 129/29; Teresa Arruda Alvim e J. Miguel Medina reputam que faltaria interesse de agir para uma segunda sentença sobre o mesmo objeto - o que tornaria "inexistente" a sentença proferida a despeito da carência de ação (ALVIM, Teresa Arruda; MEDINA, José Miguel Garcia. O dogma da coisa julgada: hipóteses de relativização. São Paulo, RT, 2003, n. 2.2, p. 38); ALVIM, Teresa Arruda; CONCEIÇÃO, Maria Lúcia Lins da; RIBEIRO, Leonardo Ferres da Silva; MELO, Rogério Licastro Torres de. Primeiros comentários ao novo Código de Processo Civil. São Paulo: RT, 2015. p. 1.373.

${ }^{6}$ RIZZI, Sérgio. Ação rescisória. cit., n. 81, p. 133-139; TEXEIRA, Sálvio. Ação rescisória: apontamentos. Revista dos Tribunais, São Paulo, v. 78, n. 646, p. 7-18, ago. 1989, n. 2.2, p. 8, e n. 2.3, p. 10 (na nota 15, p. 18, considera "nula pleno iure" a segunda decisão); PORTO, Sérgio Gilberto. Comentários ao Código de Processo Civil. São Paulo, RT, 2000. v. 6, n. 2 ao art. 485, V, p. 316; ASSIS, Araken de. Processo civil brasileiro. São Paulo, RT, 2015. p. 1.475-1.476, v. 3.; MARINONI, Luiz Guilherme. A questão das coisas julgadas contraditórias, Revista de Processo, São Paulo, v. 42, n. 271, p. 297-307, p. 301-303, set. 2017.

${ }^{7}$ Sobre os pressupostos de existência do processo e da sentença, remeto ao que escrevi no cap. 5 de Coisa julgada e sua revisão. São Paulo: RT, 2005, p. 279-375. 


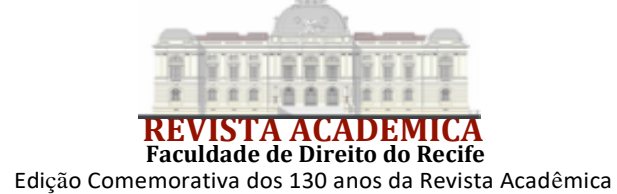

Tampouco é aceitável qualquer construção no sentido de que, uma vez estabelecida a coisa julgada, o poder jurisdicional para o exame daquele objeto processual (mesmas partes, mesmo pedido e causa de pedir) seria retirado da generalidade dos órgãos integrantes do Judiciário. A investidura jurisdicional está sempre presente quando configurados os pressupostos substancial, formal e orgânico da Jurisdição. ${ }^{8} \mathrm{O}$ agente jurisdicional está investido de jurisdição para qualquer caso que se lhe submeta.

Também não vem em socorro da tese ora criticada a ideia de que a coisa julgada eliminaria o interesse de agir para uma nova demanda sobre o mesmo objeto - de modo que seria inexistente a sentença proferida a despeito da falta desse pressuposto de admissibilidade. Primeiro, essa equiparação é discutível, por retirar a autonomia e a própria utilidade da categoria da coisa julgada. Depois, ela é, em qualquer caso, inservível para os casos de violação à dimensão positiva da coisa julgada (em que o problema não está em se repetir a demanda sobre o mesmo objeto, mas em o juiz não considerar uma premissa necessária, revestida de coisa julgada). De todo modo, ainda que se pudesse admitir tal equiparação, a sentença proferida a despeito de faltar condição da ação não é juridicamente inexistente. Não há dúvidas de que, quando formula um pedido perante o órgão jurisdicional, o autor sempre estará no exercício de um direito, uma garantia, de acesso à Justiça tenha ou não razão quanto ao mérito, estejam ou não presentes as condições da ação, apresentemse ou não os pressupostos processuais. E isso é o que basta para reconhecer que o autor, tendo formulado o pleito de tutela, começa a instituir e integra a relação processual - tenha ou não razão; careça ou não de "ação processual". Assim, cumpre reconhecer a existência jurídica da sentença de mérito proferida quando faltava condição da ação. Há um defeito, uma invalidade, mas a sentença existe: estão presentes os elementos essenciais para sua configuração: presença do juiz, presença das partes e decisum.

\section{A EFICÁCIA DA SEGUNDA SENTENÇA - O REGIME GERAL DOS ATOS DE DIREITO PÚBLICO}

Tampouco se pode dizer que, embora sendo existente a segunda sentença, a solução do conflito entre os dois comandos incompatíveis dar-se-ia com o puro e simples prevalecimento do primeiro. Duas considerações afastam essa conclusão.

A primeira é de que a lei previu expressamente o cabimento da ação rescisória contra o segundo pronunciamento (CPC, art. 966, IV). Isso significa que, decorrido o prazo sem que o específico meio de impugnação seja exercido, fica superado - torna-se irrelevante - o defeito da segunda sentença. ${ }^{9}$ E, então, "o primeiro julgado destitui-se de valor, visto que o segundo julgado implica negação de todo julgado anterior em contrário". ${ }^{10}$ Não se nega que o direito positivo poderia ter resolvido tal conflito de modo diverso. Mas, para tanto, haveria a necessidade de uma regra expressa a respeito - como há, por exemplo, no direito português (v. CPC port., arts. 675 e $813, f)$.

Daí a segunda consideração: na falta de uma regra expressa em outro sentido, vale o princípio geral aplicável a todos os campos do direito público destinado à solução de conflito entre

${ }^{8}$ TALAMINI, Eduardo. Coisa julgada e sua revisão. cit., n. 5.5.d, p. 301-305.

${ }^{9}$ MOREIRA, José Carlos Barbosa. Comentários ao CPC. cit., n. 133, p. 233 (que, porém, reconhece não ser satisfatória nenhuma das soluções: nem a de prevalência da primeira sentença, nem a de prevalência da segunda); MIRANDA, Pontes de. Tratado da ação rescisória da sentença e de outras decisões. 5. ed. Rio de Janeiro: Forense, 1976. p. 245. n. 23.

${ }^{10}$ Chiovenda, considerando regra equivalente no direito italiano (CHIOVENDA, Giuseppe. Instituições de direito processual civil. Tradução de G. Menegale. 2. ed. São Paulo: Saraiva, 1965. v. 3 , n. 73, p. 206; CHIOVENDA, Giuseppe. Principii di diritto processuale civile. 1965. 3. ed. Nápoles: Jovene, 1923. p. 900. § 76, n. 2.). 
comandos jurídicos: o ato posterior prevalece sobre o anterior (critério da "temporalidade"). ${ }^{11}$ Pode não ser a solução ideal para o impasse. Aliás, o ideal seria que o impasse nem existisse. De todo modo, se ele ocorre, essa é a solução "menos pior".

\section{BREVE REFERÊNCIA À HISTÓRIA DO DIREITO E AO DIREITO} COMPARADO

Também nesse tema é descabida a invocação do direito romano ou do antigo direito português - segundo os quais valeria sempre a primeira sentença, sendo a segunda "nula", "nenhuma". Tal solução estava indissociavelmente ligada à concepção romana clássica de nulidade como inexistência. Outros tantos defeitos que podiam ser constatados a qualquer tempo hoje se submetem inquestionavelmente ao regime pelo qual se tornam irrelevantes, se não forem impugnados oportunamente antes do trânsito em julgado ou pelo meio de rescisão da coisa julgada. ${ }^{12}$

Com a ofensa à coisa julgada, não foi diferente. Foi também abrangida pelo processo histórico de transformação dos motivos de inexistência (nullitatis) em fundamentos de impugnação contra pronunciamentos existentes. $\mathrm{Na}$ generalidade dos ordenamentos de matriz romanogermânica, a ofensa à coisa julgada passou a ser prevista, quando muito, como fundamento para a desconstituição de atos acobertados pela coisa julgada. Na Itália, cabe revocazione contra a sentença ofensiva à coisa julgada, desde que no segundo processo não tenha havido a expressa rejeição de tal alegação (CPC ital., art. 395, n. 5). Na Alemanha, é possível o emprego do remédio rescisório desde que tenha sido impossível alegar a existência da primeira coisa julgada no processo em que se formou a segunda (ZPO, art. 580, n. 7, a). Em todos esses ordenamentos, não há dúvidas de que, não havendo a desconstituição do segundo pronunciamento, ele prevalecerá. ${ }^{13}$

${ }^{11}$ Reconhecem prevalecer a segunda sentença, entre outros: MARQUES, José Frederico. Manual de Direito Processual Civil. São Paulo, Saraiva, 1975. p. 243. . v. 3, n. 691.; nota de Ada Grinover em LIEBMAN, Enrico Tullio. Eficácia e autoridade da sentença. Tradução de A. Buzaid e B. Aires. 3. ed. Rio de Janeiro: Forense, 1984, p. 242; ARAGÃO, Egas Dirceu Moniz de. Sentença e coisa julgada. Rio de Janeiro: Aide, 1992. p. 285. n. 202. ; DINAMARCO, Cândido Rangel. Instituições de direito processual civil. São Paulo: Malheiros, 2001. v. 3, n. 970, p. 328-329; THEODORO JR., Humberto. Nulidade, inexistência e rescindibilidade da sentença, Revista de Processo, São Paulo, v. 5, n. 19, p. 23-37, jul./set. 1980; NEVES, Daniel Amorim Assumpção. Novo Código de Processo Civil comentado. 2. ed. Salvador: JusPodivm, 2017. p. 1.604; ATAÍDE JR., Jaldemiro Rodrigues de. Comentários ao art. 966 do CPC/2015. In: ALVIM, Angélica Arruda; ASSIS, Araken de; ALVIM, Eduardo Arruda; LEITE, George Salomão (coord.). Comentários ao Código de Processo Civil. 2. ed. São Paulo: Saraiva, 2017, p. 1.127; CRAMER, Ronaldo. Comentários ao art. 966 do CPC/2015. In: CABRAL, Antonio do Passo; CRAMER, Ronaldo (coord.). Comentários ao novo Código de Processo Civil. 2. ed. Rio de Janeiro: Forense, 2016. p. 1.419-1.420; YARSHELL, Flávio Luiz. Ação rescisória: juízos rescindente e rescisório. São Paulo: Malheiros, 2005. p. 317-319; SILVA, Blecaute Oliveira. Conflito entre coisas julgadas no novo Código de Processo Civil. In: DIDIER JR., Fredie; CABRAL, Antonio do Passo (coord.). Grandes temas do NCPC: coisa julgada e outras estabilidades processuais. Salvador: JusPodivm, 2018. p. 136-137. v. 12. Também Pontes de Miranda afirma a preponderância da segunda sentença, ressalvando, porém, os efeitos já produzidos pela primeira (MIRANDA, Pontes de. Tratado da ação rescisória da sentença e de outras decisões. cit., n. 23 , p. 245 e 253-254). Na jurisprudência: RT 707/51, RJTJSP 88/125, RF 267/217.

${ }^{12}$ Veja-se TALAMINI, Eduardo. Coisa julgada e sua revisão. cit., cap. 4, p. 196-278.

${ }^{13}$ P. ex., na Itália, além da já citada lição de Chiovenda (nota 10, acima), v., entre outros, CARNELUTTI, Francesco. Sistema di diritto processuale civile. Pádua, Cedam, 1936. p. 314. v. 1, n. 107. ; BETTI, Emilio. Cosa giudicata e ragione fatta valere in giudizio, Rivista del diritto commerciale, Padova, v. 1, p. 544 e ss., 1929, n. 4, p. 553; REDENTI, Enrico. Diritto processuale. 4. ed. Milão: Giuffrè, 1997. p. 552. v. 2, n. 178. ; NICOLETTI, Carlo Alberto. Lineamenti istituzionali del processo civile. Milão: Giuffrè, 2002. p. 129. cap. 4, n. 12. As coisas se passam de modo diferente no direito português. Lá, a ofensa à coisa julgada também está posta como hipótese de rescisão da coisa julgada (recurso de revisão - CPC port., art. 771, g). Porém, não exercitado o remédio rescisório, prevalecerá a primeira sentença. Mas convém ressaltar: tal se dá por força de expressa previsão legal 
Aliás, nesses outros ordenamentos, o próprio cabimento do remédio rescisório por ofensa à coisa julgada já é mais restrito do que no direito brasileiro. ${ }^{14}$ Isso significa não só que o defeito em questão não afeta a existência jurídica do segundo ato, mas também que, na valoração desenvolvida em vários ordenamentos, reputa-se não se tratar de invalidade com gravidade tal que justifique sempre e em qualquer caso a desconstituição da segunda coisa julgada.

\section{A COISA JULGADA COMO GARANTIA CONSTITUCIONAL - IRRELEVÂNCIA PARA A QUESTÃo}

A circunstância de a coisa julgada estar estabelecida como garantia constitucional (CF, art. $5^{\circ}, \mathrm{XXXVI)} \mathrm{tampouco} \mathrm{permite} \mathrm{a} \mathrm{conclusão} \mathrm{de} \mathrm{que} \mathrm{deve} \mathrm{prevalecer} \mathrm{a} \mathrm{primeira} \mathrm{sentença,} \mathrm{em} \mathrm{vista}$ de uma pretensa ineficácia ou inexistência da segunda.

Em primeiro lugar, pondere-se que, a rigor, haverá duas coisas julgadas, de modo que o prestígio constitucional seria atribuível a ambas. ${ }^{15}$

Argumenta-se que em favor da primeira também se poria, além da coisa julgada, a garantia do "direito adquirido". ${ }^{16}$ Mas não é a sentença que atribui à parte o direito. A sentença apenas reconhece um direito. Portanto, a sentença favorável não significa "direito (material) adquirido". Quando muito, "adquire-se" a segurança processual da imutabilidade do comando. Mas isso é a própria coisa julgada - e assim se recai na objeção inicial.

Em segundo lugar, a coisa julgada, embora se revista de status constitucional, é delineada pela legislação infraconstitucional. São as normas infraconstitucionais que estabelecem suas hipóteses de ocorrência, limites, meios de revisão, modo de operar - e assim por diante. Trata-se de noção assente na jurisprudência constitucional. ${ }^{17}$ É o legislador infraconstitucional que define inclusive os meios de fazer valer a coisa julgada. Consequentemente lhe é dado conferir limites a tais meios - inclusive o limite decadencial para a rescisória. Por isso, e com a devida venia, não é válido o argumento de que a lei infraconstitucional não poderia limitar em dois anos o prazo para ajuizamento da rescisória por ofensa à coisa julgada.

Ademais, e se fosse procedente a tese ora criticada, ela seria aplicável não só à hipótese de violação da coisa julgada, mas a todo e qualquer caso em que a sentença revestida da coisa julgada estivesse em desacordo com uma norma constitucional - o que se descarta. Basta considerar dois exemplos. Primeiro: uma sentença sem fundamentação ofende garantia constitucional $(\mathrm{CF}$, art. 93, IX). No entanto, tal sentença não será inexistente ou absolutamente ineficaz só por isso. A própria Constituição trata a hipótese como um acaso de nulidade - de modo que, se tal sentença for de mérito e transitar em julgado, sua desconstituição dependerá de ação rescisória, a ser oportunamente ajuizada. Escoado o prazo rescisório, não haverá o que ser feito. Permanecerá a sentença sem fundamentação. O segundo exemplo: a sentença que aplica uma norma inconstitucional viola igualmente a Constituição. No entanto, o STF sempre reputou que seria

(CPC port., art. 675). E, bem por isso, a regra do art. 771, g, já era considerada desnecessária, "letra morta", por REIS, J. Alberto dos. Código de Processo Civil anotado. 1985. Coimbra: Coimbra Editora, 1985. p. 366-367. v. 6 , n. 11 , art. 771 .

${ }^{14}$ Por exemplo, na Itália, a revocazione só é admissível se o tema da ofensa à coisa julgada não tiver sido objeto de decisão no processo da sentença rescindenda (CPC ital., art. 395, 5). Na Alemanha, a ação de restituição cabe apenas se a parte tiver estado impossibilitada de demonstrar, no segundo processo, a primeira coisa julgada (ZPO, art. 580, 7, a, e 582). Semelhante limitação estava prevista no Código de Processo Civil português (de 1939) até a reforma de 1961.

${ }^{15}$ Nessa linha argumenta MOREIRA, José Carlos Barbosa. Comentários ao CPC. cit., n. 133, p. 226.

${ }^{16}$ ALVIM, Teresa Arruda. Nulidades da sentença e do processo. 4. ed. São Paulo: RT, 1997. p. 340. n. 3.1.3.

${ }^{17}$ Ver por exemplo: RTJ 159/682, rel. Min. S. Pertence; RE 226.887-PE, rel. Min. Carlos Velloso - ambos citados no RE 220.517-2, rel. Min. Celso de Mello (em RT 794/196). 


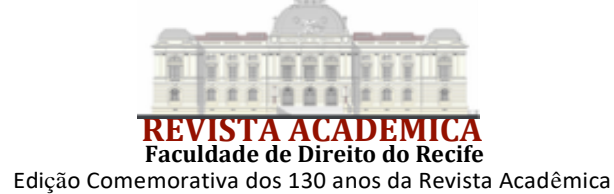

imprescindível o emprego da ação rescisória para desconstituir a sentença que tivesse aplicado a norma por ele declarada inconstitucional (e mesmo que em sede de ação direta). Tal orientação, que se estabeleceu logo nos primeiros anos de vigência do sistema de controle direto e abstrato entre nós, foi reiterado há não muitos anos em sede de repercussão geral. ${ }^{18}$

Em suma, em princípio a sentença "inconstitucional", ainda que eivada de um defeito grave, é juridicamente existente e eficaz. Se for de mérito e transitar em julgado, precisa ser desconstituída por ação rescisória, no prazo legal, sob pena de permanecer vigorando. Isso se aplica igualmente à sentença ofensiva de coisa julgada.

\section{POSSÍVEL SOLUÇÃO DE LEGE FERENDA}

De lege ferenda, seria razoável alteração no direito positivo para eliminar ou ampliar o prazo para a propositura da ação rescisória nessa hipótese. ${ }^{19}$ Algo nesses termos atualmente se dá no direito francês, em que o pourvoi en cassation poderá ser utilizado a qualquer tempo quando houver dois julgados concretamente incompatíveis entre si (art. 618 do Code de Procédure Civile). Note-se, porém, que essa hipótese é diferente da prevista no art. 617 do Nouveau Code, conforme a qual, dentro de certo prazo (ex art. 612), opõe-se o pourvoi en cassation para invalidar a segunda sentença. Já no caso do art. 618, ambas as sentenças serão simultaneamente levadas à Corte de Cassação, que irá anular uma delas, ou, se for o caso, até mesmo as duas. Nada garante que a primeira seja mantida. ${ }^{20}$ Convém meditar se um modelo semelhante seria adequado: a medida, embora sem prazo para propositura, poderia conduzir à rescisão da primeira coisa julgada (p. ex., quando os efeitos da segunda já se tivessem produzido, e os da primeira, não).

Além disso, de lege lata, nos casos gravíssimos, em que o prevalecimento da segunda sentença revele-se extremamente aviltante também para outros valores constitucionais, haverá de se cogitar da quebra atípica da segunda coisa julgada. ${ }^{21}$

\section{O POSICIONAMENTO DO STJ (EARESP 600.811)}

A orientação aqui adotada, de prevalência da segunda coisa julgada, quando não restringida, veio a ser definitivamente consagrada no STJ no início de 2020. Antes, o Superior Tribunal já havia proferido diversas decisões nesse mesmo sentido. ${ }^{22}$ Havia, no entanto, alguns

${ }^{18}$ RMS 17.976-SP, rel. Min. Amaral Santos, j. 13.09.1968, em RTJ 55/744; RE 86.056, rel. Min. Rodrigues Alckmin, j. 31.05.1977, DJU 01.07.1977; Rcl. 148, rel. Min. Moreira Alves, j. 17.06.1983, em RTJ 109/463; RE 592.912, $2^{\text {a }}$ T., Rel. Min. Celso de Mello; RE 730.462, rel. Min. Teori Zavascki (repercussão geral).

${ }^{19}$ É o que sugerem, entre outros, MOREIRA, José Carlos Barbosa. Comentários ao CPC. cit., n. 133, p. 226, nota 247, e DINAMARCO, Cândido Rangel. A instrumentalidade do processo. 3. ed. São Paulo: Malheiros, 1993. p. 75 , n. 8 , nota 23 .

${ }^{20}$ Cf. VINCENT, Jean; GUINCHARD, Serge. Procédure civil. 24. ed. Paris: Dalloz, 1996. p. 924-925. , n. 1523. Sobre a aplicação jurisprudencial dessa regra, v. as notas ao art. 618 (esp. n. 4 e 5) da edição anotada de VINCENT, Jean; GUINCHARD, Serge. Nouveau Code de Procédure Civile. 80. ed. Paris: Dalloz, 1998 (com referências bibliográficas e jurisprudenciais sem indicação de autoria).

${ }^{21}$ Mais uma vez remeto à minha monografia específica sobre o tema (TALAMINI, Eduardo. Coisa julgada e sua revisão. cit., cap. 13, p. 561-613).

22 STJ, $1^{\text {a }}$ Turma, REsp 1.573.169, rel. Min. GURGEL FARIA, decisão monocrática 10.04.2017, DJe 18.04.2017; STJ, $2^{\mathrm{a}}$ Turma, REsp 598.148, v.u., rel. Min. HERMAN BENJAMIN, j. 25.08.2009, DJe 31.08.2009; STJ, $2^{\mathrm{a}}$ Turma, AgRg no AREsp 200.454, v.u., rel. Min. OG FERNANDES, j. 17.10.2013, DJe 24.10.2013; STJ, $2^{\mathrm{a}}$ Turma, REsp 1.524.123, v.u., rel. Min. HERMAN BENJAMIN, j. 26.05.2015, DJe 30.06.2015; STJ, $2^{\mathrm{a}}$ Turma, AgInt no REsp 1.684.068, v.u., rel. Min. OG FERNANDES, j. 24.10.2017, DJe 07.11.2017; STJ, 4 ${ }^{\mathrm{a}}$ Turma, AgInt no REsp 1.270.008, v.u., rel. Min. LUIS FELIPE SALOMÃO, j. 21.08.2018, DJe 27.08.2018; STJ, $5^{\mathrm{a}}$ Turma, REsp 604.880, v.u., rel. Min. ARNALDO ESTEVES LIMA, j. 22.05.2007, DJ 11.06.2007, p. 347; STJ, 


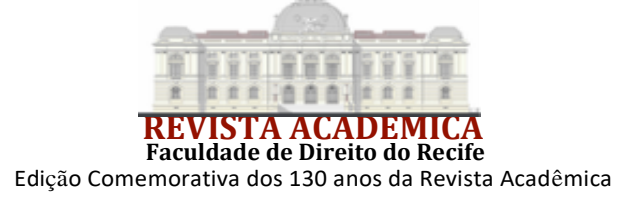

pronunciamentos divergentes. ${ }^{23}$ De todo modo, em embargos de divergência julgados pela Corte Especial (EAREsp 600.811), consolidou-se a orientação já antes prevalecente:

PROCESSUAL CIVIL. EMBARGOS DE DIVERGÊNCIA EM AGRAVO EM RECURSO ESPECIAL. DISSENSO ESTABELECIDO ENTRE O ARESTO EMBARGADO E PARADIGMAS INVOCADOS. CONFLITO ENTRE COISAS JULGADAS. CRITÉRIO TEMPORAL PARA SE DETERMINAR A PREVALÊNCIA DA PRIMEIRA OU DA SEGUNDA DECISÃO. DIVERGÊNCIA QUE SE RESOLVE, NO SENTIDO DE PREVALECER A DECISÃO QUE POR ÚLTIMO TRANSITOU EM JULGADO, DESDE QUE NÃO DESCONSTITUÍDA POR AÇÃO RESCISÓRIA. DISCUSSÃO ACERCA DE PONTO SUSCITADO PELA PARTE EMBARGADA DE QUE, NO CASO, NÃO EXISTIRIAM DUAS COISAS JULGADAS. QUESTÃO A SER DIRIMIDA PELO ÓRGÃO FRACIONÁRIO. EMBARGOS DE DIVERGÊNCIA PROVIDOS PARCIALMENTE.

1. A questão debatida neste recurso, de início, reporta-se à divergência quanto à tese firmada no aresto embargado de que, no conflito entre duas coisas julgadas, prevaleceria a primeira decisão que transitou em julgado. Tal entendimento conflita com diversos outros julgados desta Corte Superior, nos quais a tese estabelecida foi a de que deve prevalecer a decisão que por último se formou, desde que não desconstituída por ação rescisória. Diante disso, há de se conhecer dos embargos de divergência, diante do dissenso devidamente caracterizado.

2. Nesse particular, deve ser confirmado, no âmbito desta Corte Especial, o entendimento majoritário dos órgãos fracionários deste Superior Tribunal de Justiça, na seguinte forma: "No conflito entre sentenças, prevalece aquela que por último transitou em julgado, enquanto não desconstituída mediante Ação Rescisória" (REsp 598.148/SP, Rel. Ministro Herman Benjamin, Segunda Turma, julgado em 25/8/2009, DJe 31/8/2009).

3. Entendimento jurisprudencial que alinha ao magistério de eminentes processualistas: "Em regra, após o trânsito em julgado (que, aqui, de modo algum se preexclui), a nulidade converte-se em simples rescindibilidade. O defeito, arguível em recurso como motivo de nulidade, caso subsista, não impede que a decisão, uma vez preclusas as vias recursais, surta efeito até que seja desconstituída, mediante rescisão (BARBOSA, 1985, v. 5, p. 111, grifo do autor) BARBOSA MOREIRA, José Carlos. Comentários ao Código de Processo Civil, $5^{\text {a }}$ ed, Forense: 1985 , vol. V, p. 111, grifo do autor). Na lição de Pontes de Miranda, após a rescindibilidade da sentença, "vale a segunda, e não a primeira,

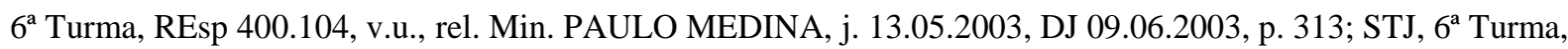
AgRg no REsp 643.998, v.u., rel. Min. CELSO LIMONGI (Des. convocado TJSP), j. 15.12.2009, DJe

$1^{\circ} .02 .2010 ;$ STJ, $1^{\mathrm{a}}$ Turma, REsp 1.598.866, rel. Min. SÉRGIO KUKINA, decisão monocrática 03.08.2020, DJe 05.08.2020; STJ, $2^{\text {a }}$ Turma, Ag em REsp 931.954, rel. Min. DIVA MALERBI (Des. convocada do TRF3), decisão monocrática 22.06.2016, DJe 28.06.2016; STJ, 2 a Turma, Ag em REsp 794.603, rel. Min. Herman Benjamin, decisão monocrática 14.10.2015, DJe, 10.11.2015; STJ, $2^{\mathrm{a}}$ Turma, Ag em REsp 794.603, rel. Min. Herman Benjamin, decisão monocrática 14.10.2015, DJe 10.11.2015; STJ, $2^{\mathrm{a}}$ Turma, REsp 1.464.033, rel. Min. Herman Benjamin, decisão monocrática 23.09.2014, DJe, 09.10.2014; STJ, $2^{\mathrm{a}}$ Turma, REsp 1.343.751, rel. Min. Mauro Campbell Marques, decisão monocrática 13.09.2013, DJe 18.09.2013; STJ, 2 ${ }^{\mathrm{a}}$ Turma, REsp 1.343.728, rel. Min. Humberto Martins, decisão monocrática 19.09.2012, DJe 17.09.2012; STJ, $3^{\mathrm{a}}$ Turma, Pet no REsp 1.451.815, Rel. Min. Ricardo Villas Bôas Cueva, decisão monocrática 19.04.2017, DJe 04.05.2017; STJ, $4^{\mathrm{a}}$ Turma, AREsp 508.022, rel. Min. Luís Felipe Salomão, decisão monocrática 07.05.2014, DJe 27.05.2014.

${ }^{23}$ STJ, $3^{\text {a }}$ Turma, REsp 1.354.225, v.u., rel. Min. PAULO DE TARSO SANSEVERINO, j. 24.02.2015, DJe 05.03.2015; STJ, $3^{\mathrm{a}}$ Turma, AgInt no AREsp 600.811, v.u., rel. Min. PAULO DE TARSO SANSEVERINO, j.

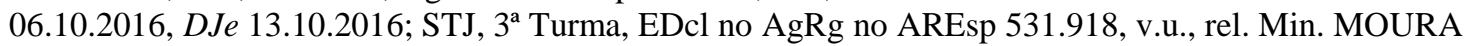

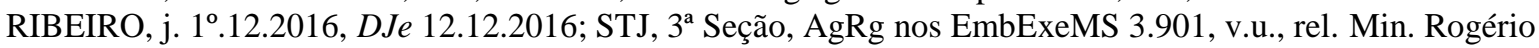
Schietti Cruz, j. 14.11.2018, DJe 21.11.2018. 
salvo se a primeira já se executou, ou começou de executar-se". (Comentários ao Código de Processo Civil. 3. ed. , t. 6. Rio de Janeiro: Forense, 2002, p. 214).

4. Firmada essa premissa, que diz respeito ao primeiro aspecto a ser definido no âmbito deste recurso de divergência, a análise de questão relevante suscitada pela parte embargada, no sentido de que, no caso, não existiriam duas coisas julgadas, deve ser feita pelo órgão fracionário. É que a atuação desta Corte Especial deve cingir-se à definição da tese, e, em consequência, o feito deve retornar à eg. Terceira Turma, a fim de, com base na tese ora estabelecida, rejulgar a questão, diante da matéria reportada pela parte embargada. 5. Embargos de divergência providos parcialmente. ${ }^{24}$

\section{REFERÊNCIAS}

ALVIM, Teresa Arruda. Nulidades da sentença e do processo. 4. ed. São Paulo: RT, 1997.

ALVIM, Teresa Arruda; MEDINA, José Miguel Garcia. O dogma da coisa julgada: hipóteses de relativização. São Paulo: RT, 2003.

ALVIM, Teresa Arruda; CONCEIÇÃO, Maria Lúcia Lins da; RIBEIRO, Leonardo Ferres da Silva; MELO, Rogério Licastro Torres de. Primeiros comentários ao novo Código de Processo Civil. São Paulo: RT, 2015.

ARAGÃO, Egas Moniz de. Sentença e coisa julgada. Rio de Janeiro: Aide, 1992.

ASSIS, Araken de. Processo civil brasileiro. São Paulo: RT, 2015. v. 3.

ATAÍDE JR., Jaldemiro Rodrigues de. Comentários ao art. 966 do CPC/2015. In: ALVIM, Angélica Arruda; ASSIS, Araken de; ALVIM, Eduardo Arruda; LEITE, George Salomão (coord.). Comentários ao Código de Processo Civil. 2. ed. São Paulo: Saraiva, 2017.

BETTI, Emilio. Cosa giudicata e ragione fatta valere in giudizio. Rivista del diritto commerciale, Padova, v. 1, p. 544 e ss., 1929.

CARNELUTTI, Francesco. Sistema di diritto processuale civile. Pádua: Cedam, 1936. v. 1.

CHIOVENDA, Giuseppe. Instituições de direito processual civil. Tradução de G. Menegale. 2. ed. São Paulo: Saraiva, 1965. v. 3.

CHIOVENDA, Giuseppe. Principii di diritto processuale civile. 1965. 3. ed. Nápoles: Jovene, 1923.

CHIOVENDA, Giuseppe. A instrumentalidade do processo. 3. ed. São Paulo: Malheiros, 1993.

${ }^{24}$ BRASIL. Superior Tribunal de Justiça. Corte Especial. EAREsp 600.811, v.m., rel. Min. OG FERNANDES, 04 de dezembro de 2019. DJe, 07 de fevereiro de 2020. 


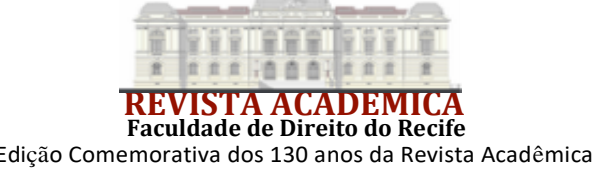

CRAMER, Ronaldo. Comentários ao art. 966 do CPC/2015. In: CABRAL, Antonio do Passo; CRAMER, Ronaldo (coord.). Comentários ao novo Código de Processo Civil. 2. ed. Rio de Janeiro: Forense, 2016.

DINAMARCO, Cândido Rangel. Instituições de direito processual civil. São Paulo: Malheiros, 2001. v. 3.

LIEBMAN, Enrico Tullio. Eficácia e autoridade da sentença. Tradução de A. Buzaid e B. Aires. 3. ed. Rio de Janeiro: Forense, 1984.

MARINONI, Luiz Guilherme. A questão das coisas julgadas contraditórias. Revista de Processo, São Paulo, v. 42, n. 271, p. 297-307, set. 2017.

MARQUES, José Frederico. Manual de Direito Processual Civil. São Paulo: Saraiva, 1975. v. 3.

MIRANDA, Pontes de. Tratado da ação rescisória da sentença e de outras decisões. 5. ed. Rio de Janeiro: Forense, 1976.

MOREIRA, José Carlos Barbosa. Comentários ao CPC. 11. ed. Rio de Janeiro: Forense, 2003. v. 5.

NEGRÃO, Theotonio. Código de Processo Civil e legislação processual em vigor. 35. ed. São Paulo: Saraiva, 2003.

NEVES, Daniel Amorim Assumpção. Novo Código de Processo Civil comentado. 2. ed. Salvador: JusPodivm, 2017.

NICOLETTI, Carlo Alberto. Lineamenti istituzionali del processo civile. Milão: Giuffrè, 2002.

PORTO, Sérgio Gilberto. Comentários ao Código de Processo Civil. São Paulo: RT, 2000. v. 6.

REDENTI, Enrico. Diritto processuale. 4. ed. Milão: Giuffrè, 1997. v. 2.

REIS, J. Alberto dos. Código de Processo Civil anotado. 1985. Coimbra: Coimbra Editora, 1985. v. 6.

RIZZI, Sérgio. Ação rescisória. São Paulo: RT, 1979.

SILVA, Blecaute Oliveira. Conflito entre coisas julgadas no novo Código de Processo Civil. In: DIDIER JR., Fredie; CABRAL, Antonio do Passo (coord.). Grandes temas do NCPC: coisa julgada e outras estabilidades processuais. Salvador: JusPodivm, 2018. v. 12.

TALAMINI, Eduardo. Coisa julgada e sua revisão. São Paulo: RT, 2005.

TEXEIRA, Sálvio. Ação rescisória: apontamentos. Revista dos Tribunais, São Paulo, v. 78, n. 646, p. 7-18, ago. 1989.

THEODORO JR., Humberto. Nulidade, inexistência e rescindibilidade da sentença. Revista de Processo, São Paulo, v. 5, n. 19, p. 23-37, jul./set. 1980. 
VINCENT, Jean; GUINCHARD, Serge. Procédure civil. 24. ed. Paris: Dalloz, 1996.

VINCENT, Jean; GUINCHARD, Serge. Nouveau Code de Procédure Civile. 80. ed. Paris: Dalloz, 1998.

YARSHELL, Flávio Luiz. Ação rescisória: juízos rescindente e rescisório. São Paulo:

Malheiros, 2005. 